Canadian Studies in Population, Vol. 32.2, 2005, pp. 155-176

\title{
Korean Migration to North America: Some Prices That Matter
}

\author{
J.D. Han \\ Peter Ibbott \\ King's University College, \\ University of Western Ontario \\ London, Ontario, Canada
}

\begin{abstract}
The empirical migration literature has emphasized the role that differences in the return to human capital play in the migration decision. In this paper, we argue that many migrants are also concerned with differences in the return to the financial capital that they bring with them. One testable implication of the theory is that depreciation in the value of the Canadian dollar relative to the U.S. dollar should cause some migrants to substitute Canada for the United States as their destination of choice. Using data on Korean immigration to Canada and the United States, we estimate a regression model to test this hypothesis. The statistical evidence strongly supports a conclusion that exchange rate movements can cause some migrants to substitute destinations.
\end{abstract}

Key Words: International migration, exchange rates 


\section{Résumé}

La littérature empirique sur la migration met en évidence le rôle que les différences de rendement sur le capital humain jouent dans la décision de migrer. Dans cet article, nous examinons l'hypothèse que beaucoup de migrants sont aussi intéressés au rendement sur le capital financier qu'ils apportent avec eux. Une des implications testables de cette théorie est le fait que la dépréciation de la valeur du dollar canadien en relation avec le dollar américain devrait causer certains migrants à substituer le Canada aux État-Unis comme lieu de destination privilégiée. En nous servant des données sur la migration coréenne au Canada et aux États-Unis, nous avons estimé un modèle de régression pour tester notre hypothèse. Les données statistiques démontrent fortement que les fluctuations de taux de change peuvent causer certains migrants à substituer leur destination.

Mots-clés: La migration internationale, les taux de changes.

\section{Introduction}

Koreans have been immigrating to North America for just over a century, with the United States being the largest recipient of this migration flow. ${ }^{1}$ As might be expected, the rapid convergence of Korean incomes with North America incomes has coincided with a decline in the flow of Korean migrants to North America. Despite this decline, Korean migration to Canada has recently grown (Figure 1). Something has caused Korean migrants to substitute destinations.

Most economic theories of migration begin with the idea that migration flows are the result of decisions over where to invest human capital. A potential migrant evaluates the present value of their human capital in the home and destination country. If the present value in the destination country exceeds the full moving costs and present value of their human capital in the home country, then the potential migrant chooses migration. This human capital framework presents straightforward and testable implications for the pattern of migration flows. The most obvious are that: migrants tend to be young; migrants move from areas where the return to human capital is low to areas where the return to human capital is high; reductions in the costs associated with migration will increase migration flows; greater physical and cultural distances increase the costs and hence reduce the rate of migration. Not surprisingly, the evidence from a large empirical literature strongly supports these predictions (Ghatak et.al. 1996). 
Further developments of the human capital story have led to other predictions. Todaro (1969) and Harris and Todaro (1970) introduced uncertainty into the migration decision by considering the impact of high unemployment in the migrant's destination. As with any other investment, the decision-maker would simply evaluate the expected net present value of the migration investment. The obvious prediction that increasing unemployment in the destination country reduces the expected return to human capital in the destination and so dampens migration flows has also been supported in numerous empirical studies.

\section{Figure 1.}

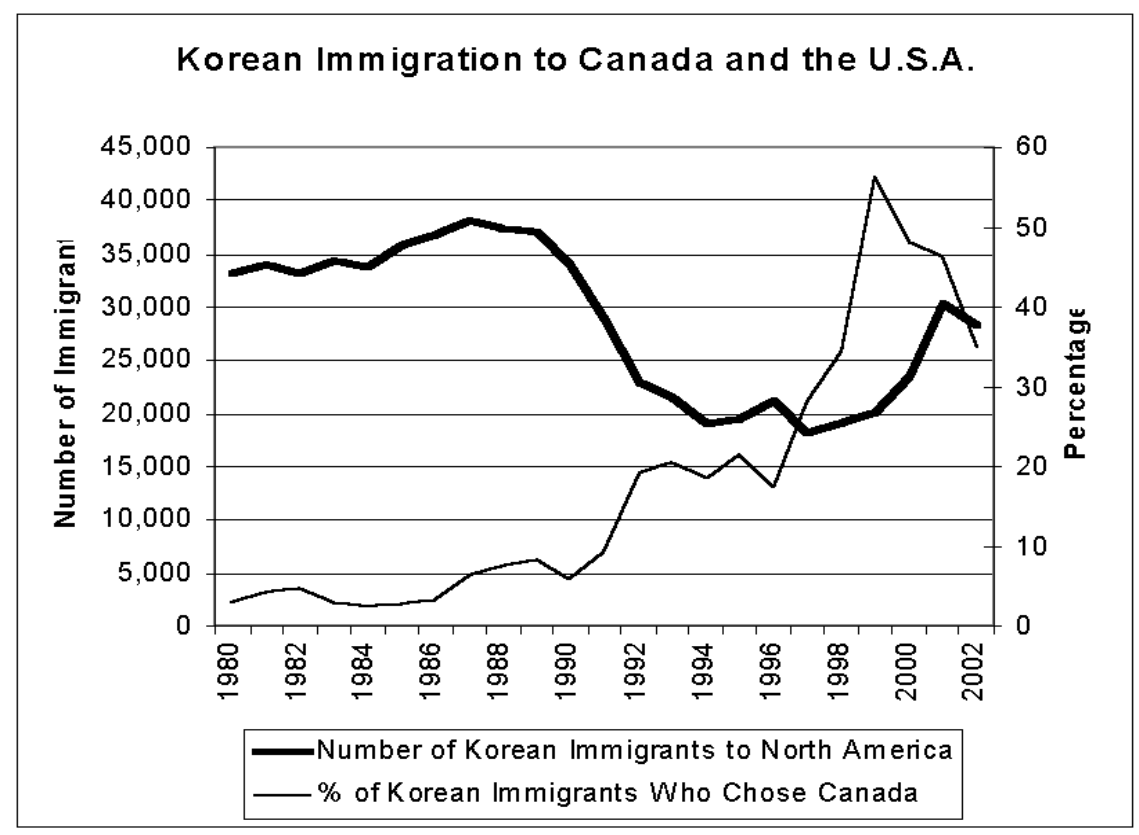

Source: Citizenship and Immigration Canada and U.S. Office of Immigration Statistics

The problem presented by Korean migration to Canada over the 1990's is that Canadian earnings fell and unemployment rose relative the United States. The human capital model seems to predict that Canada should have seen immigration flows fall over the period, and fall more quickly than the United States. 


\section{J. D. Han and Peter Ibbot}

Other elaborations on the human capital story offer no easy solution to the puzzle. A more sophisticated model of heterogeneous labor that self selects was introduced by Sjaastad (1962), and developed by Borjas $(1987,1989,1994)$ and Chiswick (2000). The usual predictions of the human capital story carry through, along with some unexpected predictions about how increasing inequality in the destination country increases immigration of individuals with large human capital endowments. Hatton (2003) uses the framework to show that an increase in the inequality in the destination country should increase the rate of flow of migrants. The puzzle this time is that while inequality rose in the Canada, it rose more quickly in the United States (Figure 2). Again, the expectation created by theory is that Korean migration to Canada should be declining not rising.

\section{Figure 2.}

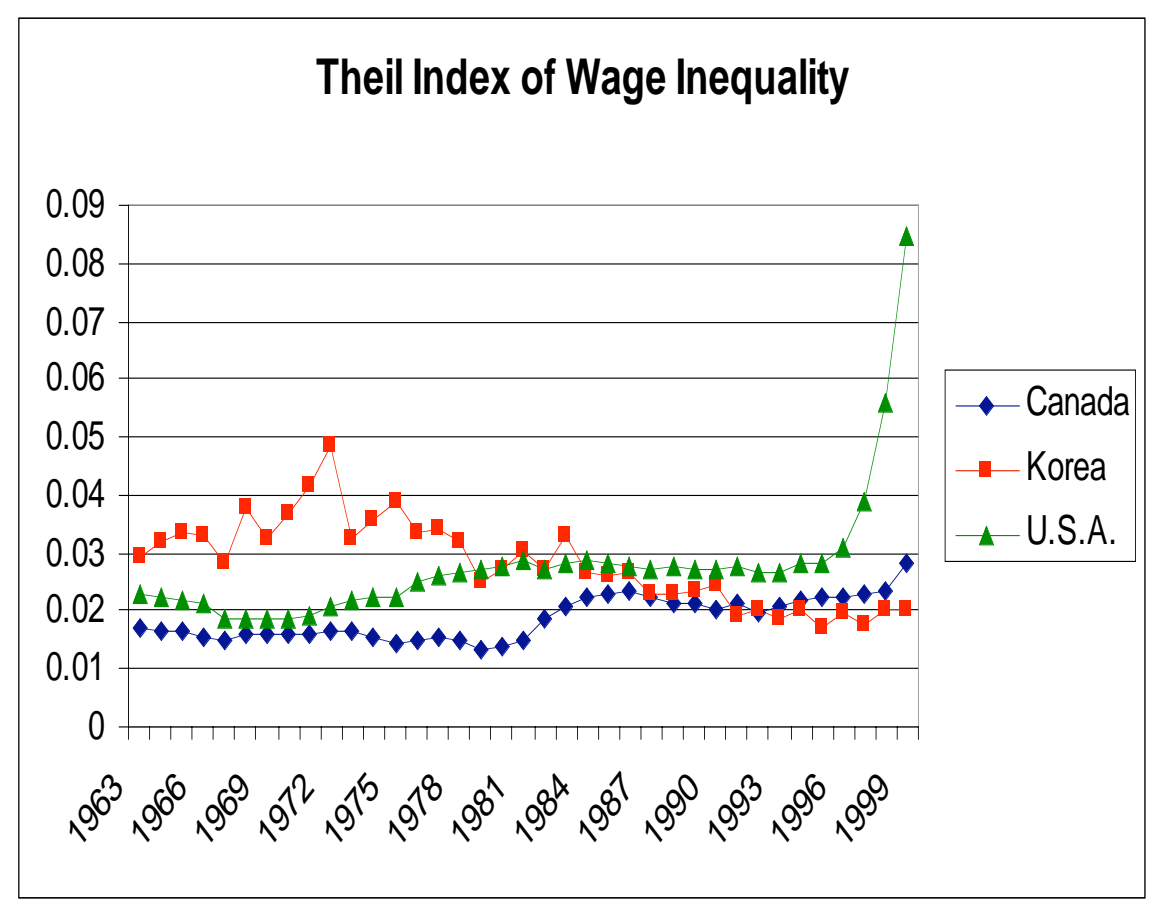


The 'new economics of migration' literature (Stark, 1991) has explored whether migration might usefully be examined as part of a portfolio investment decision of risk diversifying families. Accordingly, the expectation is that families would choose to invest their human capital assets over geographically dispersed and independent markets. Given the integration of Canadian and U.S. markets, it seems likely that risk diversifying family investors would have evaluated a Canadian situated human capital asset as being outside of the efficient portfolio. Again the human capital theory prediction is at odds with experience.

Other human capital models have emphasized search costs (Maier, 1985 and Berninghaus and Seifert-Vogt, 1991), the option value of waiting (Burda, 1995), liquidity constraints (Massey, 1988, Ghatak and Levine, 1994, and Hatton and Williamson, 2002), and social network effects (Bauer and Zimmerman, 1995). None of these provides any obvious explanation of the rapid increase in Korean migration to Canada in the 1990's. When the human capital model is extended to examine the impact of non-price factors such as political stability, political rights, and individual freedoms in the source country, the consistent finding is that they are all important determinants (Kamemera et. al., 2000). Since Korean civil rights and political stability were increasing over this period, it is hard to understand why such changes would lead Korean migrants to substitute Canada for the United States as a destination.

To get a handle on the apparent linkages between Canada and the United States, it is necessary to develop a model that can detect substitution. Baker and Benjamin's (1995) examination of migration from the Asia-Pacific region to Canada estimated a number of human capital models consistent with the direction of most of the empirical literature, and found the usual strong evidence supporting the predictions of the Harris-Todaro model and the common prediction that population density in the source country is positively related to the rate of migration to a Canadian destination. When they extended their model to allow migrants to substitute between Canada and the United States, the model no longer performed well at all, unless country dummy variables were added to the model. Once, these country fixed effects were added, the expected substitution effect reappeared. Canadian convergence to U.S. capita GDP caused some immigrants to substitute Canada for the United States. The statistical importance of the country fixed effects and the fragility of their substitution finding to a small change in the specification caused them to conclude that "noneconomic supply-side variables are the most important determinants of immigrant flows between the Asia Pacific countries and the United States and Canada" (318). 


\title{
J. D. Han and Peter Ibbot
}

If we accept their conclusion, we should look to non-price social changes in Korea to explain the massive substitutions occurring over the second half of the 1990's. One obvious possibility is that the move to democracy has paradoxically increased friction with the United States. At the same time, the number of Canadians working in Korea as teachers has grown dramatically to the point where Canadians have become the largest group of foreign teachers working in Korea. The combination of potent anti-Americanism and personal connections to Canada through teachers might have made Canada appear more attractive to prospective migrants.

An alternative possibility is that U.S. and Canadian demand for immigrants is the determining factor in the measured flows. DeVoretz $(1995,349-351)$ points to evidence in Green and Green (1995) to suggest that Canadian tinkering in immigrant admissions criteria over their 1974-92 study period prevented Baker and Benjamin from identifying the supply relationship that they were attempting to estimate. Interestingly, Green and Green (1999) have recently presented evidence showing that in the late 1980's the Canadian government abandoned its attempts to match inflows with domestic labor market conditions, "switching almost completely to long-term goals" $(1999,447)$. With this switch to a policy of steady demand for immigrants, the identification problem recedes.

Given that the rapid growth in Korean migration to Canada occurred during a period of stable immigration policies, attention to changes affecting the supply of Koreans to North America seems reasonable. Interestingly, the rapid growth in Korean migrants choosing Canada as a destination has a parallel in the rapid growth in Korean visitors and Korean students choosing Canada as a destination (Figure 3). This parallel movement points toward some common cause. In the next section we propose a simple extension of the human capital model to consider how moving other capital assets abroad might influence the migration decision. The model suggests that the relative movements in exchange rates might have played an important role in causing Koreans to substitute Canada for the United States as a destination. The model is then estimated and conclusions drawn.

\begin{abstract}
A Model
There is evidence in the regional migration literature suggesting that physical capital and its price play an important role in the migration decision. In Lucas' (1985) study of rural-urban migration in Botswana, a multinomial logit model confirmed the predictions of the Harris-Todaro model and indicated that the number of cattle owned played a role in the decision to migrate. In developed country studies of internal migration, differences in housing costs were shown to
\end{abstract}


strongly influence regional migration in Italy (Attanasio and Padoa Shioppa, 1991), in Spain (Bentolila and Dolado, 1991), and the United States (Gabrel, Shack-Marquez and Wascher, 1992). T he implication is that households bring more than human capital with them. I

Figure 3. Korean Student Enrolments, Immigration and Travel to Canada: 1980-2002

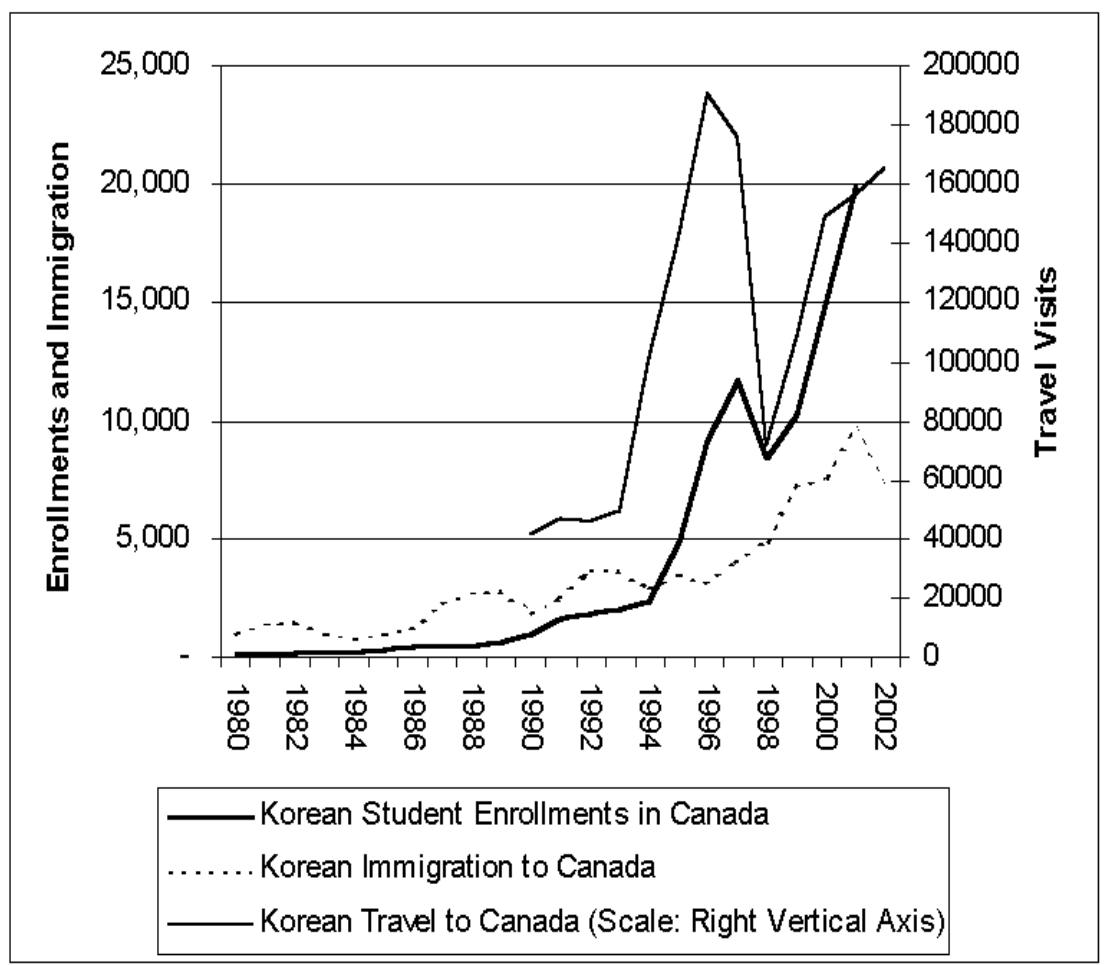

Source: Citizenship and Immigration Canada.

To introduce this into an international migration setting, consider the following model of a Korean migrant's decision to move to North America. As with most human capital stories, each family (i) is endowed with $\mathrm{H}_{\mathrm{i}}$ units of human capital which (with an appropriate choice of units) yield an expected present value of $\mathrm{H}_{\mathrm{i}}$ 


\section{J. D. Han and Peter Ibbot}

\$U.S. In the destination country, this human capital might be expected to earn a premium $w_{c}$ in Canada and a premium $w_{u s}$ in the United States of America. The expected present value of the family's human capital therefore be $\mathrm{w}_{\mathrm{c}}{ }^{*} \mathrm{H}_{\mathrm{i}}$ in Canada and $\mathrm{w}_{\mathrm{us}} * \mathrm{H}_{\mathrm{i}}$ in the United States of America. All units are in U.S. dollars.

In addition, the family might also posses $\mathrm{K}_{\mathrm{i}}$ units of a capital good which (with an appropriate choice of units) has a liquidation value of $\mathrm{P}_{\mathrm{k}} \mathrm{K}_{\mathrm{i}}$ won, where $\mathrm{P}_{\mathrm{k}}$ is the price per unit of capital. This could be converted into U.S. dollars to provide $\mathrm{e}_{\mathrm{us}} \mathrm{P}_{\mathrm{k}} \mathrm{K}_{\mathrm{i}}$ U.S. dollars of financial capital, where $\mathrm{e}_{\mathrm{us}}$ is the won cost of \$1 U.S. With this financial capital, the family can buy $e_{u s}\left(\mathrm{P}_{\mathrm{k}} / \mathrm{P}_{\mathrm{us}}\right) \mathrm{K}_{\mathrm{i}}$ units of capital in the United States. Similarly, the same family can purchase $e_{c}\left(P_{k} / P_{c}\right) K_{i}$ units of capital in Canada.

If the household's preferences can be represented by a utility function (U) then the household will decide to migrate to the U.S. if

$$
\begin{aligned}
& \mathrm{U}\left(\mathrm{w}_{\mathrm{us}} \mathrm{H}_{\mathrm{i}}, \mathrm{e}_{\mathrm{us}}\left(\mathrm{P}_{\mathrm{k}} / \mathrm{P}_{\mathrm{us}}\right) \mathrm{K}_{\mathrm{i}}\right)>\mathrm{U}\left(\mathrm{H}_{\mathrm{i}}, \mathrm{K}_{\mathrm{i}}\right) \text { and } \mathrm{U}\left(\mathrm{w}_{\mathrm{us}} \mathrm{H}_{\mathrm{i}}, \mathrm{e}_{\mathrm{us}}\left(\mathrm{P}_{\mathrm{k}} / \mathrm{P}_{\mathrm{us}}\right) \mathrm{K}_{\mathrm{i}}\right)> \\
& \mathrm{U}\left(\mathrm{w}_{\mathrm{c}} \mathrm{H}_{\mathrm{i}}, \mathrm{e}_{\mathrm{c}}\left(\mathrm{P}_{\mathrm{k}} / \mathrm{P}_{\mathrm{c}}\right) \mathrm{K}_{\mathrm{i}}\right),
\end{aligned}
$$

and migrate to Canada if

$$
\begin{aligned}
& \mathrm{U}\left(\mathrm{w}_{\mathrm{c}} \mathrm{H}_{\mathrm{i}}, \mathrm{e}_{\mathrm{c}}\left(\mathrm{P}_{\mathrm{k}} / \mathrm{P}_{\mathrm{c}}\right) \mathrm{K}_{\mathrm{i}}\right)>\mathrm{U}\left(\mathrm{H}_{\mathrm{i}}, \mathrm{K}_{\mathrm{i}}\right) \text { and } \mathrm{U}\left(\mathrm{w}_{\mathrm{c}} \mathrm{H}_{\mathrm{i}}, \mathrm{e}_{\mathrm{c}}\left(\mathrm{P}_{\mathrm{k}} / \mathrm{P}_{\mathrm{c}}\right) \mathrm{K}_{\mathrm{i}}\right)>\mathrm{U}\left(\mathrm{w}_{\mathrm{us}} \mathrm{H}_{\mathrm{i}},\right. \\
& \left.\mathrm{e}_{\mathrm{us}}\left(\mathrm{P}_{\mathrm{k}} / \mathrm{P}_{\mathrm{us}}\right) \mathrm{K}_{\mathrm{i}}\right)
\end{aligned}
$$

and stay at home otherwise.

If each family's preferences can be represented by some utility function that is increasing in its two arguments, then it is clear that rate of Korean migration to Canada (to the U.S) will be increasing (decreasing) in $\mathrm{w}_{\mathrm{c}} / \mathrm{w}_{\mathrm{us}}$ and increasing (decreasing) in $\left(\mathrm{e}_{\mathrm{c}} / \mathrm{e}_{\mathrm{us}}\right)\left(\mathrm{P}_{\mathrm{us}} / \mathrm{P}_{\mathrm{c}}\right)$. While it might be possible to specify a utility function and derive an estimation equation directly, we prefer to apply some of the empirical models in the literature to Korean migration to North America.

The first model we wish to investigate is the Baker and Benjamin (1995) model used to examine Asia Pacific immigration to Canada. Adopting this to the story of Korean migration to North America yields:

$$
\begin{aligned}
& \ln \left(\mathrm{IMM}_{\mathrm{Ct}}\right)=\beta_{\mathrm{C} 0}+\beta_{\mathrm{C} 1} \ln \left(\mathrm{PCGDP}_{\mathrm{Kt}}\right)+\beta_{\mathrm{C} 2} \ln \left(\mathrm{PCGDP}_{\mathrm{Ct}}\right)+\beta_{\mathrm{C} 3} \mathrm{URATE}_{\mathrm{Ct}} \\
& +\beta_{\mathrm{C} 4} \ln \left(\mathrm{POPDEN}_{\mathrm{Kt}}\right)+\varepsilon_{\mathrm{CKt}} \\
& \ln \left(\mathrm{IMM}_{\mathrm{Ut}}\right)=\beta_{\mathrm{U} 0}+\beta_{\mathrm{U} 1} \ln \left(\mathrm{PCGDP}_{\mathrm{Kt}}\right)+\beta_{\mathrm{U} 2} \ln \left(\mathrm{PCGDP}_{\mathrm{Ut}}\right)+\beta_{\mathrm{U} 3} \mathrm{URATE}_{\mathrm{Ut}} \\
& +\beta_{\mathrm{U} 4} \ln \left(\mathrm{POPDEN}_{\mathrm{Kt}}\right)+\varepsilon_{\mathrm{UKt}}
\end{aligned}
$$


Baker and Benjamin then differenced the two equations and assumed that $\beta_{\mathrm{C} 1}=$ $\beta_{\mathrm{U} 1}$ and $\beta_{\mathrm{C} 4}=\beta_{\mathrm{U} 4}$. This they argued was equivalent to assuming that "from the individual migrant's perspective, a change in local income or local population density had the same impact on their propensity to migrate to either the United States or Canada, holding U.S. and Canadian opportunities constant" (315). The result was the following estimating equation.

$$
\Delta \ln \left(\mathrm{IMM}_{\mathrm{t}}\right)=\beta_{0}^{\prime}+\beta_{1}^{\prime} \Delta \ln \left(\mathrm{PCGDP}_{\mathrm{t}}\right)+\beta_{2}^{\prime} \Delta \mathrm{URATE}_{\mathrm{t}}+\Upsilon_{\mathrm{t}}
$$

This empirical model implicitly assumes that the premium to human capital in Canada and the U.S. ( $\mathrm{w}_{\mathrm{c}} / \mathrm{w}_{\mathrm{us}}$ in the previous discussion) can be proxied by the relative difference in real GDP per capita and differences in the unemployment rate. $^{2}$ Our extension builds on this practical compromise by introducing the difference between the exchange rate in Canada and the United States as an added explanatory variable. The resulting model would is:

$$
\Delta \ln \left(\mathrm{IMM}_{\mathrm{t}}\right)=\beta_{0}^{\prime}+\beta_{1}^{\prime} \Delta \ln \left(\mathrm{PCGDP}_{\mathrm{t}}\right)+\beta_{2}^{\prime} \Delta \mathrm{URATE}_{\mathrm{t}}+\beta_{3}^{\prime} \Delta \ln \left(\mathrm{X}_{\mathrm{t}}\right)+\Upsilon_{\mathrm{t}}
$$

where $\Delta \ln \left(\mathrm{X}_{\mathrm{t}}\right)$ is the Canada-U.S. difference in the log of the exchange rate. The expectation is that depreciation in the Canadian currency relative to the U.S. currency should cause some Korean migrants to consider substituting Canada for the United States as a destination. We also expect that auto-correlated errors are likely to be a problem, and that the differencing might transform the data sufficiently to reduce the influence of auto-correlated errors on the estimation.

Hatton (2003) provides an alternative approach by estimating the determinants of migration flows in a random effects panel model. Given the limited data we have at our disposal, it is difficult to adapt such a model to the task of examining the substitution effect. The model in equation 4 allows testing for a substitution effect in a parsimonious manner.

\section{Findings}

The point of departure for our study was Baker and Benjamin (1994) results indicating that country fixed effects were particularly important. Our first step was to re-examine their two models using a longer time series. The parameter estimates for equations 1, and 2 together with the Baker and Benjamin estimates are presented in Table 1. A parameter estimate with a superscript star indicates a significant t-statistic at the 5\% level. The estimated standard errors are presented in brackets below each parameter estimate. This convention is continued in the remaining tables. 
Table 1.

\begin{tabular}{|c|c|c|c|c|c|c|}
\hline & Intercept & $\ln \left(\mathrm{PCGDP}_{\mathrm{Kt}}\right)$ & $\ln \left(\mathrm{PCGDP}_{\mathrm{it}}\right)$ & URATE $_{\text {it }}$ & $\ln \left(\mathrm{POPDEN}_{\mathrm{Kt}}\right)$ & $\mathrm{R}^{2}$ \\
\hline $\begin{array}{l}\text { Baker and } \\
\text { Benjamin }\end{array}$ & $\begin{array}{c}-27.440^{*} \\
(8.270)\end{array}$ & $\begin{array}{l}-1.007^{*} \\
(0.159)\end{array}$ & $\begin{array}{l}4.178^{*} \\
(0.899)\end{array}$ & $\begin{array}{l}-0.072 \\
(0.055)\end{array}$ & $\begin{array}{l}0.574 * \\
(0.088)\end{array}$ & 0.25 \\
\hline $\begin{array}{c}\text { Equation } 1 \\
\text { (Canada) }\end{array}$ & $\begin{array}{l}24.926 \\
(12.97)\end{array}$ & $\begin{array}{c}0.4672 \\
(0.7996)\end{array}$ & $\begin{array}{c}-6.7821^{*} \\
(1.978)\end{array}$ & $\begin{array}{l}-0.23171^{*} \\
(0.04586)\end{array}$ & $\begin{array}{c}14.647^{*} \\
(5.040)\end{array}$ & 0.80 \\
\hline $\begin{array}{c}\text { Equation } 2 \\
\text { (U.S.A) }\end{array}$ & $\begin{array}{c}-18.624 * \\
(9.004)\end{array}$ & $\begin{array}{r}-0.29444 \\
(0.3828)\end{array}$ & $\begin{array}{c}8.2940 * \\
(1.717)\end{array}$ & $\begin{array}{l}0.17158^{*} \\
(0.03527)\end{array}$ & $\begin{array}{c}-16.305^{*} \\
(3.063)\end{array}$ & 0.79 \\
\hline
\end{tabular}

In comparing our estimates of equation 1 and 2 with Baker and Benjamin's results, a couple of remarkable differences become apparent. First of all, the impact of Korean GDP on migration flows seems to be unimportant. Second, the impact of Canadian GDP on Korean migration to Canada seems to be opposite to expectations. So also is the impact of U.S. unemployment on Korean migration to the United States. Perhaps the most surprising result is that the population density variable appears to be significant in both the Canadian and the U.S. regression, but the sign is significantly negative in the United States. ${ }^{3}$ One likely explanation is that the steady increase in Korean population density simply acts like a time trend variable, furthering the suspicion of specification problems in the Baker and Benjamin model.

We explored many sensible extensions of the Baker and Benjamin model to see if the addition of plausible variables might deliver estimates that are more consistent with theory. By and large, the results were far from satisfactory. The most obvious extension was to consider whether unemployment in Korea was having a significant impact on the migration decision. Presented in Table 2 as equations 1.1 and 1.2 , the results very clearly indicate that Korean unemployment is not the missing piece. While it does cause the estimates to appear to firm up, the estimates continue to suggest that an increase in Canadian income reduces Korean immigration. Moreover, if we include the population density variable, the estimated parameters in the model do not look that different from the model without Korean unemployment.

The low Durban-Watson statistic indicates that autocorrelation is a problem. Attempts to correct for this using a Cochrane-Orcutt type procedure did change the sign on the $\ln \left(\right.$ PCGDP $\left._{\mathrm{CANt}}\right)$ variable but the $\mathrm{R}^{2}$ dropped to about 0.5 and none of the variables in the regression were significant according to a standard ttest. 
Korean Migration to North America: Some Prices that Matter

Table 2.

\begin{tabular}{|c|c|c|c|c|}
\hline & Intercept & $\ln \left(\mathrm{PCGDP}_{\mathrm{Kt}}\right)$ & $\ln \left(\mathrm{PCGDP}_{\mathrm{Ct}}\right)$ & URATE $_{\mathrm{Ct}}$ \\
\hline \multirow{2}{*}{ Eqt. 1 Canada } & 24.926 & 0.4672 & $-6.7821^{*}$ & $-0.23171^{*}$ \\
\hline & -12.97 & -0.7996 & -1.978 & -0.04586 \\
\hline Eqt 1.1 & $\begin{array}{c}40.16^{*} \\
(18.69)\end{array}$ & $\begin{array}{c}2.582^{*} \\
(0.664)\end{array}$ & -13.001439 & -0.0172143 \\
\hline \multirow[t]{2}{*}{ Eqt.1.2 } & $\begin{array}{c}22.98 \\
(18.06)\end{array}$ & $\begin{array}{c}0.367 \\
(1.031)\end{array}$ & -14.8517793 & -0.0133792 \\
\hline & URATE $_{\mathrm{Kt}}$ & $\ln \left(\mathrm{POPDEN}_{\mathrm{Kt}}\right)$ & $\mathrm{R}^{2}$ & DW \\
\hline Eqt. 1 Canada & & $\begin{array}{c}14.647^{*} \\
-5.04\end{array}$ & 0.8 & \\
\hline Eqt 1.1 & $\begin{array}{c}0.0565 \\
(0.0576)\end{array}$ & & 0.75 & 0.964 \\
\hline Eqt.1.2 & $\begin{array}{l}-0.00911 \\
(0.05756)\end{array}$ & $\begin{array}{l}15.036^{*} \\
(5.695)\end{array}$ & 0.8 & 0.992 \\
\hline
\end{tabular}

Rethinking the problem, we noted that Green and Green (1999) had identified a change in Canadian Immigration policy in the late 1980's. ${ }^{4}$ The government abandoned fine tuning the points system to match immigration flows to local labor market conditions. To capture the impact of these changes, we introduced a structural dummy variable for the years 1988 through to 2003. The dummy variable alone or interacting with the other variables did seem to improve the fit somewhat, but the model still showed the problems identified in the earlier specifications. Specifically, the parameter on $\ln \left(\right.$ PCGDP $\left._{\mathrm{CANt}}\right)$ was still negative, and the Durban-Watson statistic remained low.

The hypothesis that we advanced in the previous section is that exchange rates may play a role in the location decision of migrating Koreans. Unfortunately, extending the model to consider the impact of foreign exchange rates facing 


\section{J. D. Han and Peter Ibbot}

Koreans leads only to a marginal improvements. One interesting result is that the Canadian cost of U.S. dollars provides sharper estimates than the Korean Won cost of Canadian dollars or the Korean Won cost of U.S. dollars. This suggests to us that there is non-zero cross-price elasticity between the Korean immigration to the U.S. and Canada.

Presented below in Table 3 are the results of estimates from one of these extensions to equation 1 . The results are not strong. The only parameter that seems remotely significant is the time dummy (D). The interactive dummy variables for Canadian GDP (DUMC) and Korean GDP (DUMK) have the expected signs but they are not strong estimates. The log of the Canadian cost of U.S. dollars (LGCXR) was the best performing exchange rate from those tested. The estimated value suggests that increases in the value of this variable (depreciation in the currency) cause immigration by Koreans to Canada to decline. This is completely counter to expectations. Not much should be read into this result as the t-statistic is low. More importantly, the Durbin-Watson statistic is low $(\mathrm{DW}=1.21)$, indicating important problems remain with the model.

Table 3.

\begin{tabular}{|c|c|c|c|c|}
\hline Intercept & $\ln \left(\mathrm{PCGDP}_{\mathrm{Kt}}\right)$ & $\ln \left(\mathrm{PCGDP}_{\mathrm{Ct}}\right)$ & URATE $_{\mathrm{Ct}}$ & URATE $_{\mathrm{Kt}}$ \\
\hline 74.902 & 3.503 & -9.759 & -0.1795 & 0.07462 \\
\hline-43.43 & -2.445 & -6.264 & -0.1025 & -0.06082 \\
\hline $\mathrm{D}$ & DUMC & DUMK & LGCXR & \\
\hline-71.85 & 8.2862 & -1.198 & -1.2063 & \\
\hline-34.69 & -5.069 & -2.066 & -2 & \\
\hline
\end{tabular}


When attention is turned to Korean immigration to the United States (equation 2 in Table 4), the regression results seem more in line of existing studies. According to the estimates, an increase in U.S. GDP is related to increases in Korean immigration to the United States, while an increase in Korean GDP is related (weakly) to decreases. The only peculiarity is the indication that increases in U.S. unemployment is related to increases in Korean immigration to the United States. As with the Canadian case, extension of the model to consider the impact of Korean unemployment (equation 2.1 in Table 4) does not provide a demonstrable improvement. More importantly, the apparent significance of the trending population density variable remains and the Durbin-Watson statistic is low. Extending the model with time dummies and exchange rates does not bring any improvement, and more importantly does not eliminate the problem of autocorrelated errors.

Table 4.

\begin{tabular}{|c|c|c|c|c|}
\hline & Intercept & $\ln \left(\mathrm{PCGDP}_{\mathrm{Kt}}\right)$ & $\ln \left(\mathrm{PCGDP}_{\mathrm{Ut}}\right.$ & URATE $_{\mathrm{Ut}}$ \\
\hline Eqt. 2 USA & -167.58 & $\begin{array}{l}-0.2944 \\
(0.3828)\end{array}$ & $\begin{array}{l}8.2940^{*} \\
(1.717)\end{array}$ & $\begin{array}{l}0.17158^{*} \\
(0.03527)\end{array}$ \\
\hline \multirow[t]{2}{*}{ Eqt.2.1 } & -228.4389 & $\begin{array}{c}-0.33151 \\
(0.4587)\end{array}$ & $\begin{array}{l}8.4372^{*} \\
(1.983)\end{array}$ & $\begin{array}{l}0.17505^{*} \\
(0.0425)\end{array}$ \\
\hline & $\mathrm{URATE}_{\mathrm{Kt}}$ & $\ln \left(\mathrm{POPDEN}_{\mathrm{Kt}}\right)$ & $\mathrm{R}^{2}$ & DW \\
\hline Eqt. 2 USA & & -49.942215 & 0.80 & \\
\hline Eqt.2.1 & $\begin{array}{l}-0.00399 \\
(0.0260)\end{array}$ & $\begin{array}{l}16.317^{*} \\
(3.123)\end{array}$ & 0.79 & 1.28 \\
\hline
\end{tabular}




\section{J. D. Han and Peter Ibbot}

The finding of a serious specification problem is consistent with our argument that changes in exchange rates may cause price substitution by migrating Koreans. Equations 1 and 2 are not well equipped to uncover this substitution. As discussed earlier, Baker and Benjamin's second model (equation 3) offers a more natural model for examining the impact of exchange rate movements in the migration decisions (equation 4).

Before estimating equation 4, we re-estimated equation 3 for Korean migration to North America. The results presented in Table 5 are suggestive, as the estimates indicate a strongly significant negative parameter estimate for the difference in Canadian and U.S. income. This should not be that surprising as Baker and Benjamin found that the positive estimate quickly became negative with the addition of country dummy variables and a time trend. The results also show that the DW statistic does not support a conclusion of serial correlation in equation 3. Given all of this, the evidence seems to point to Korean migrants perversely choosing Canada over the United States when Canadian incomes fall relative to the United States.

Table 5.

\begin{tabular}{c|c|c|c|c|c}
\hline & Intercept & $\Delta \ln \left(\right.$ PCGDP $\left._{\mathrm{t}}\right)$ & $\Delta$ URATE $_{\mathrm{t}}$ & $\mathrm{R}^{2}$ & $\mathrm{DW}$ \\
\hline \hline $\begin{array}{c}\text { Baker and } \\
\text { Benjamin }\end{array}$ & $-1.354^{*}$ & 4.178 & -0.082 & 0.41 & \\
\hline Equation 3 & -2.3868972 & -3.608 & -0.075 & & \\
\hline
\end{tabular}

While this perverse choice might be explained by non-price sociological factors, there remains the possibility that other prices matter, and that the absence of these prices constitutes a specification problem. If our argument in the last section is correct, then it is likely that the exchange rate may be important. To investigate this, we estimated equation 4 to see whether the addition of the Canadian dollar cost of US dollars altered the estimates. Presented in Table 6, the results do not provide as clear an adjudication of the issue as might be desired. The Durbin-Watson statistic and R squares improve greatly, but the sign of the income variable continues to suggest that Korean migrants make perverse 
choices. The exchange rate variable has the expected sign, but the t-statistic is low.

We argued earlier that there was reason to suspect a structural change in the late 1980 's and our regressions supported this view. Introducing a dummy variable to capture this structural change does alter the results in ways consistent with theoretical expectations. Presented in Table 6 as equation 4.1, the estimated parameters on the extended model present a dramatically different picture. The negative parameter on the difference in GDP appears to be insignificantly different from zero, while the exchange rate parameter suggests a significant positive relationship. In other words, differences in Canadian and U.S. GDP appear less important than the influence of the depreciation of the Canadian dollar in the rapid increase in Korean migration to Canada during the 1990's.

In equation 4.2 , we examined whether replacing the nominal exchange rate with a real exchange rate weighted with a Canadian and U.S. housing price index changed the results. The estimates suggest that there is little reason to prefer either exchange rate. In equations 4.3 and 4.4 we examined the impact of dropping all the variables except the exchange rate and the dummy variable. The results are surprisingly strong, reinforcing our conclusion that migrants do substitute when prices change.

\section{Conclusions}

"differences in net economic advantages, chiefly differences in wages, are the main causes of migration” (Hicks, 1932, p.76)

The new migration literature has not substantially altered our understanding of the role that prices play in the migration decision. Instead of Hicks' emphasis on wage differentials, the new literature emphasizes differences in the return to human capital. While this is more nuanced than the earlier view, the literature has continued to view the price of labor as the price that matters. In this paper, we have attempted to outline reasons why the price of currency matters. While the results are preliminary, the evidence is consistent with a view that relatively prosperous migrants are influenced by exchange rate movements in deciding between potential destinations.

More generally, we have initiated an examination of migration flows in which migrants substitute destinations when prices change. The empirical and theoretical literature is virtually silent on this important aspect of economic choice. Our contention is that the relative importance of country dummy variables in the empirical literature may at least be partly an artifact of a focus 
Table 6

\begin{tabular}{|c|c|c|c|c|c|c|}
\hline & Eqt. 3 & Eqt. 4 & Eqt. 4.1 & Eqt. 4.2 & Eqt. 4.3 & Eqt. 4.4 \\
\hline Intercept & -2.3868972 & -2.7539267 & $\begin{array}{c}-1.7804 \\
(3.437)\end{array}$ & $\begin{array}{c}-1.5910 \\
(3.295)\end{array}$ & $\begin{array}{c}-5.2128 \\
(0.348)\end{array}$ & $\begin{array}{c}-5.7693 \\
(0.395)\end{array}$ \\
\hline $\mathrm{D}$ & & & $\begin{array}{c}-2.8504 \\
(3.488)\end{array}$ & $\begin{array}{l}-3.4065 \\
(3.327)\end{array}$ & $\begin{array}{c}1.8443 \\
(0.2175)\end{array}$ & $\begin{array}{l}0.2065 \\
(8.574)\end{array}$ \\
\hline$\Delta \ln \left(\mathrm{PCGDP}_{\mathrm{t}}\right)$ & -104.375075 & -82.734468 & $\begin{array}{l}11.192 \\
(24.78)\end{array}$ & $\begin{array}{l}16.752 \\
(23.93)\end{array}$ & & \\
\hline $\mathrm{D}^{*} \Delta \ln \left(\mathrm{PCGDP}_{\mathrm{t}}\right)$ & & & $\begin{array}{l}-27.104 \\
(24.82)\end{array}$ & $\begin{array}{c}-31.338 \\
(23.76)\end{array}$ & & \\
\hline$\Delta$ URATE $_{\mathrm{t}}$ & -0.05643795 & -0.0754425 & -0.048656435 & -0.04172 & & \\
\hline $\ln (\mathrm{CXR})$ & & $\begin{array}{l}1.7915 \\
(1.082)\end{array}$ & $\begin{array}{c}3.5030 * \\
(1.129)\end{array}$ & & $\begin{array}{c}6.1322 \\
(0.9674)\end{array}$ & \\
\hline $\ln (\mathrm{WCXR})$ & & & & $\begin{array}{l}2.1275^{*} \\
(0.626)\end{array}$ & & $\begin{array}{l}3.4781^{*} \\
(0.509)\end{array}$ \\
\hline $\mathrm{R}^{2}$ & 0.78 & 0.88 & 0.93 & 0.93 & 0.87 & 0.88 \\
\hline DW & 1.749 & 1.905 & 2.146 & 2.077 & 2.13 & 2.084 \\
\hline
\end{tabular}


on the determinants of national in-migration or out-migration. ${ }^{5}$ Such models cannot easily capture substitution of one destination over another by migrants. Unfortunately, our results are not yet strong enough to allow us to draw definitive conclusions about whether such substitutions are as important as we suspect. To explore this more thoroughly, we need to determine whether similar results can be found with other relatively prosperous migrant groups. We also need to think more carefully about how to empirically model migration within a demand theoretic framework.

\section{End Notes:}

1. The large Korean-American community recently celebrated a century of Korean immigration to the United States of America. The earliest migrants went to Hawaii in the early part of the $20^{\text {th }}$ Century. Today, the KoreanCanadian community is a little less than $10 \%$ of the size of the KoreanAmerican community. The 2001 Canadian Census indicates that there are 101,715 Canadians of Korean descent, while the 2000 U.S. Census reports 1,076,872 Americans of Korean descent.

2. A fairly substantial literature, most recently in Hatton (2003), has demonstrated that the ratio of inequality of incomes also proxies for differences in the return to human capital, with more unequal countries delivering a higher (relative) return to human capital. We will be exploring this possibility in future research.

3. The $\mathrm{R}^{2}$ values are much higher for the recent estimates than Baker and Benjamin found. When Baker and Benjamin estimated introduced country dummy variables to capture the country specific effects, the $\mathrm{R}^{2}$ jumped to 0.93. Given the much larger dataset that they were working with (sample size of 187 versus the 30 years in our time series), the $\mathrm{R}^{2}$ for our estimates seems entirely plausible.

4. Coincidentally, the Seoul Summer Olympics occurred in 1988. This event was a watershed moment which ushered in changes in the way Korean society related to the world. The previous 40 years of American influence began to be replaced by a more global outlook. At this time Canada emerged as a close alternative (substitute) to the United States in the minds of many Koreans. 


\section{J. D. Han and Peter Ibbot}

5. There is a substantive literature on migration into a single country. More recent examples include migration to Germany (Rotte and Vogler, 1998) to the U.S. (Clark, Hatton and Williamson, 2002), and to Britain (Hatton, 2003).

\section{References:}

Attanasio O.P. and F. Padoa Schioppa. 1991. "Regional Inequalities, Migration and Mismatch in Italy, 1960-86" in Padoa Schioppa (Ed.), Mismatch and Labour Mobility. Cambridge: Cambridge University Press and CEPR, 237-320.

Baker, M., and D. Benjamin. 1996. "Asia Pacific Immigration and the Canadian Economy," 303-356. in The Asia Pacific Region in the Global Economy: A Canadian Perspective," (Ed.) Richard G. Harris. Calgary: University of Calgary Press.

Bauer, T. and K.F. Zimmerman. 1995. "Modelling international migration: economic and econometric issues" in van der Erf R. and Heering, L. (Eds.) Causes of Interntational Migration. Proceedings of a Workshop, Luxembourg, 14-16 December 1994._ Eurostat, Luxembourg, 95-115.

Bentolila, S. and J.J. Dolado. 1991. "Mismatch and Internal Migration in Spain, 1982-86", in Padoa-Schioppa (1991) 182-234.

Berninghaus, S. and H.G. Seifert-Vogt. 1991. International Migration under Incomplete Information. Berlin: Springer-Verlag.

Borjas, G.J. 1987. "Self Selection and the Earning of Immigrants". American Economic Review 77, 531-553.

Borjas, G.J. 1989. "Immigrant and Emmigrant Earnings: A Longitudinal Study", Economic Inquiry, 27, 21-37.

Borjas, G.J. 1994. "The Economics of Immigration". Journal of Economic Literature, 32, 1667-1717.

Burda, M.C. 1995. “Migration and the Option Value of Waiting”, CEPR Discussion Paper No. 906. 
Chiswick, B.R. 2000. “ Are Immigrants Favorably Self-Selected? An Economic Analysis," in C.D. Brettell and J.F. Hollifield (Eds.), Migration Theory: Talking Across Disciplines. New York: Routledge.

Clark, X., T.J. Hatton, and J.G. Williamson. 2002. "Where Do US Immigrants Come From? Policy and Sending Country Fundamentals," NBER Working Paper 8998, National Bureau of Economic Research, Cambridge, Mass. (June).

DeVoretz, Don. 1995. Diminishing Returns: The Economics of Canada's Recent Immigration Policy. Toronto: C.D.Howe Institute and the Laurier Institute.

Gabriel, S.A., J. Shack-Marquez, and W.L. Wascher. 1992. "Regional HousePrice Dispersion and Interregional Migration,” Journal of Housing Economics, 2, 235-56.

Ghatak, S. and P.L. Levine. 1994. “A Note on Migration with Borrowing Constraints," Scandinavian Journal of Development, December, 19-38.

Ghatak, S., P.L. Levine, and S.W. Price. 1996. "Migration Theories and Evidence: An Assessment," Journal of Economic Surveys, 10, 159-98.

Green, A.G. and D.A. Green.1995. "Canadian Immigration Policy: the Effectiveness of the Points System and other Instruments". Canadian Journal of Economics, 28, 1006-41.

Green, A.G. and D.A. Green. 1999. "The Economic Goals of Canada's Immigration Policy: Past and Present”. Canadian Public PolicyAnalyse de Politiques, 25, 425-51.

Hatton, T.J. and J.G. Williamson. 2002. "What Fundamentals Drive World Migration," Working Paper: University of Essex.

Hatton, T.J. 2003. “ Explaining Trends in UK Migration”. Working Paper: University of Essex.

Harris, J.R. and M.P. Todaro. 1970. "Migration, Unemployment and Development: A Two-Sector Analysis," American Economic Review, 60, 126-42.

Hicks, John.1932. The Theory of Wages. London: MacMillan. 
Kamemera, D., V.I. Oguledo, and B. Davis. 2000. “A Gravity Model Analysis of International Migration to North America,” Applied Economics, 32, 1745-55.

Leacy, F.H. (ed.). 1983. Historical Statistics of Canada, Second Edition, Statistics Canada.

Lucas, R.E.B. 1985. "Migration Among the Botswana," Economic Journal, 95, 358-82.

Maier, G. 1985. "Cumulative Causation and Selectivity in Labor Market Oriented Migration Caused by Imperfect Information," Regional Studies , 19, 231-41.

Massey, D.S. 1988. "Economic Development and International Migration in Comparative Perspective," Population and Development Review , 14(3), 383-413.

Padoa-Schioppa, F. (Ed.). 1991. Mismatch and Labour Mobility. Cambridge: Cambridge University Press and CEPR.

Rotte, R. and M. Vogler. 1998. "Determinants of International Migration: Empirical Evidence for Migration from Developing Countries to Germany," IZA Discussion Paper No. 12.

Sjaastadt, L. 1962. "The Costs and Returns of Human Migration,” Journal of Political Economy, 70(5, Part 2), S80-S93.

Stark, O. 1991. The Migration of Labor. Oxford: Blackwell.

Todaro, M.P. 1969. “A Model of Labour Migration and Urban Employment in Less Developed Countries,” American Economic Review, 59, 138-48.

van der Erf R. and L. Heering. (Eds.). 1994. Causes of Interntational Migration. Proceedings of a Workshop, Luxembourg, 14-16 December 1994._Eurostat, Luxembourg, 95-115. 


\section{Data Appendix}

In the following appendix we provide details on the sources and manipulation of data used in the regressions.

$\mathbf{I M} \mathbf{M}_{\mathbf{C t}}=$ Korean Immigration to Canada.

The annual flow of Korean immigrants to Canada was taken from a variety of Citizenship and Immigration Canada publications. Between 1973 and 1996, several different issues of "Citizenship and Immigration Statistics" were consulted. The data between 1997 and 2002 was obtained from several different issues of "Facts and Figures: Immigration Overview". The spring 2004 edition of "The Monitor" reported the number of Korean immigrants arriving in Canada in 2003. All of these publications are available in pdf format at http://www.cic.gc.ca .

$\mathbf{I M M}_{\mathbf{U t}}=$ Korean Immigration to U.S.A.

The annual flow of Korean immigrants to U.S.A. was taken from various years of the "Yearbook of Immigration Statistics" published by the Office of Immigration Statistics of the U.S. Department of Homeland Security. This is available at http://uscis.gov/graphics/index.htm .

PCGDP $_{\mathbf{K t}}=$ Korean Per Capita Income in Constant (1992) U.S. dollars. For the years up to 2000, the GDP per capita data was collected from the Heston and Summers Penn World Tables, version 6.1. For the years 2001, 2002, and 2003, the series was extrapolated using the growth in the constant dollar series of GDP per capita. The source for this data was the KOSIS Statistical Database from Korean National Statistics Office (KNSO). This is available at www.nso.go.kr.

PCGDP $_{\mathbf{C t}}=$ Canadian Per Capita Income in Constant (1992) U.S. dollars For the years up to 2000, the GDP per capita data was collected from the Heston and Summers Penn World Tables, version 6.1. For the years 2001, 2002, and 2003 , the series was extrapolated using the growth in the constant dollar series of GDP per capita. The source for this data was the Statistics Canada CANSIM table 380-0002 (cat.\# 13-001-XIB). This is available at www.statcan.ca/english/Pgdb/econ05.htm.

PCGDP $_{\mathbf{U t}}=$ American Per Capita Income in Constant (1992) U.S. dollars For the years up to 2000, the GDP per capita data was collected from the Heston and Summers Penn World Tables, version 6.1. For the years 2001, 2002, and 2003 , the series was extrapolated using the growth in the constant dollar series of GDP per capita. The source for this data was the NIPA tables at the U.S. 
Department of Commerce, Bureau of Economic Analysis. This is available at www.bea.doc.gov/bea/dn/nipaweb.

URATE $_{\mathbf{C t}}=$ Unemployment Rate in Canada

The Canadian unemployment rate series was constructed from Leacy (1983) and Statistics Canada's CANSIM II Series V2062815.

URATE $_{\mathrm{Ut}}=$ Unemployment Rate in U.S.A.

The unemployment rate series for the United States was taken from the U.S. Bureau of Labor Statistics Current Population Survey. The data is available at http://www.bls.gov/cps/home.htm\#empstat .

POPDEN $_{\mathbf{K t}}=$ Population Density in Korea

The population density time series is from the World Bank's World Development Indicators.

$\mathbf{X}_{\mathrm{Ct}}=$ Cost of a U.S. Dollar in Canadian Dollars.

The Penn World Tables, version 6.1 provided the exchange rates to 2000. The remaining years in the series were obtained from the Federal Reserve, Statistical Release G.5A.

$\mathbf{X}_{\mathrm{Ut}}=1$ for all years.

$\Delta \ln \left(\mathbf{X}_{\mathbf{t}}\right)=\ln \left(\mathbf{X}_{\mathrm{Ct}}\right)-\ln \left(\mathbf{X}_{\mathrm{Ut}}\right)$

$\Delta \ln \left(\mathbf{I M M}_{\mathrm{t}}\right)=\ln \left(\mathbf{I M} \mathbf{M}_{\mathrm{Ct}}\right)-\ln \left(\mathbf{I M M}_{\mathrm{Ct}}\right)$

$\Delta \ln \left(\right.$ PCGDP $\left._{\mathrm{t}}\right)=\ln \left(\mathbf{P C G D P}_{\mathrm{Ct}}\right)-\ln \left(\mathbf{P C G D P}_{\mathrm{Ut}}\right)$

$\triangle \mathrm{URATE}_{\mathrm{t}}=\mathrm{URATE}_{\mathrm{Ct}}-\mathrm{URATE}_{\mathrm{Ut}}$ 